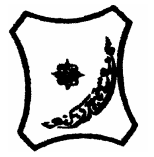

Bayero Journal of Pure and Applied Sciences, 9(2): 121 - 124

Received: November, 2016

Accepted: November, 2016

ISSN $2006-6996$

\title{
LEVELS OF TOTAL PHENOLIC AND FLAVONOIDS IN Abelmoschus esculentus L. FROM SOME IRRIGATION AREAS OF KANO STATE-NIGERIA
}

\author{
${ }^{1}$ Mohammed, M.I., ${ }^{2}$ Bayero, A.S. and ${ }^{1}$ Shettima, U.I. \\ ${ }^{1}$ Department of Pure and Industrial Chemistry, Bayero University, Kano. \\ P.M.B 3011, Kano-Nigeria \\ ${ }^{2}$ Department of Chemistry, Northwest University, Kano. \\ P.M.B.3220,Kano-Nigeria \\ *Correspondence author: umarshettima@rocketmail.com, mimuhammad.chm@buk.edu.ng
}

\begin{abstract}
Vegetables are rich in polyphenols, flavonoids, glucosinolates, vitamin $C$ and their hydrolysis products which may have antioxidant and anticancer properties. This study was carried out to assess the level of total phenolic and flavonoids in selected vegetables from different sampling areas of Kano state-Nigeria. Total phenolic and flavonoid contents in the extracts were determined by Rhodanine and $\mathrm{AlCl}_{3}$ reagents and their amount calculated as gallic acid equivalent (GAE) and rutin equivalent (RE) fresh weight respectively, using UV-VIS spectrophotometer. The result show that, the levels of total Phenolics and Flavonoid contents in okra (AbelmoschusesculentusL) vegetable samples among seven different sampling areas (viz: Bebeji, Kura, Tiga, Minjibir, Tudun Wada, Garun Malam and Chalawa) of Kano-state, Nigeria were determined. Levels of Total phenolic content ranged from $33.33 \pm 0.02$ to $22.07 \pm 0.02 \mathrm{mg}$ of gallic acid equivalent per gram of fresh matter and for flavanoid ranged from $29.97 \pm 0.03$ to $10.97 \pm 0.01 \mathrm{mg}$ of rutin equivalent per gram of fresh matter. The highest content of total phenolic in Okra was found in Bebeji sample and highest content of flavonoid was found in Minjibir sample. The results obtained revealed that, the Okra samples analyzed are potential sources of the bioactive compounds analyzed.
\end{abstract}

Key words: Flavonoid, phenolic, okra,Irrigation areas.

\section{INTRODUCTION}

Vegetables have been used as a source of food and medicine due to their abundant chemical properties since time immemorial (Sinha et. al., 2010). Crude extracts of vegetables and other plant materials rich in phenol content and flavonoids are of boosting interest in food industry and medical field. Phenolic compounds have an aromatic ring that contains various attached substituent group such as hydroxyl $(-\mathrm{OH})$, carboxyl $(-\mathrm{COOH})$ and methoxy $\left(-\mathrm{OCH}_{3}\right)$ group and often other non-aromatic ring structures. Phenolics hinder oxidative degradation of lipids and thereby enhance the excellence and nutritional value of food. Phenolics possess a wide spectrum of biochemical activities such as antioxidant, anti mutagenic, anti carcinogenic as well as ability of modifying gene expression (Srivastava et. al., 2013). More than 400 flavonoids have been identified in different higher and lower plant species (Srivastava et. al., 2013). Flavonoids are a group of poly phenolic compounds with known properties which include free radical scavenging, inhibition of hydrolytic and oxidative enzymes and anti-inflammatory action. Due to its antioxidant properties it can interfere with the oxidative process by reacting with free radicals chelating, catalytic metals and also by acting as oxygen scavengers (Srivastava et. al., 2013).OKRA (Abelmoschusesculentus L.) is an annual herb belonging to the family of Malvaceae, is one of the most important vegetables grown in Nigeria. It is widely grown for its tender fruits and young leaves. It is easy to cultivate and grows well in both tropical and temperate zones, that is, it is widely planted from Africa to Asia, and from Southern Europe to America. Since the discovery of its nutrition, it is widely cultivated in north and south China, in recent years. It has been the preferred vegetable for the Olympic athletes of the Beijing Olympic Games (Haibing et. al. 2012). For its functional characters, it has some interesting names, such as 'green pana' in Japan and 'plant Viagra' in the USA (Kang et.al., 2010). Okra is becoming a lot more popular all over the world .Nutritionally, it has been reported that there are many useful substances in the seeds of okra, such as, flavones, polysaccharide, pectin, trace elements, and amino acids (Adelakun et. al., 2009). Modern medical research provides that the extract of the fruit has the ability of resisting fatigue, and has anti-aging and anti-oxidant properties (Arapitsas, 2008). With the larger consumer demand for functional food, much more attention is paid to okra by our society, for its special functional and nutrition value.There exist certain important medicinal attribute for okra, which is given to people suffering from renal colic, leucorrhoea, spermatorrhoea, chronic dysentery and general weakness. Due to high iodine content, the fruits are useful for controlling goiter and leaves of okra are used in Turkey for preparation of medicines to reduce inflammation (Singh et. al., 2007). 
Except for a few report on the presence of the total or individual phenolics, there is a lack of information on the nature of phenolic acids in commercial varieties and plant parts of okra. They also contribute to the astringent taste and thus to overall flavor of the food. Besides, there exist reports showing pronounced physiological and biological properties of a number of phenolic acids, namely, tannic, gallic, caffeic and cinnamaic acids. It is reported that vegetables constitute an important source of dietary intake of polyphenols and phenolic acids account for almost one third of the total intake of phenolics compound (Scalbert and Williamson, 2000).

\section{MATERIALS AND METHODS}

\section{Plant Materials}

Vegetable samples Okra (Abelmoschusesculentus L.,), used in this study were obtained from Tudun Wada, Tiga, Bebeji, Garun Malam, Minjibir and Chalawa irrigation areas of Kano state, Nigeria.

\section{Samples Pretreatment}

The samples were properly washed with distilled water and air dried at room temperature. They were ground into fine powder and kept for analysis.

\section{Preparation of Standard}

A stock solution of Gallic acid was prepared by dissolving $10 \mathrm{mg}$ of gallic acid in $2 \mathrm{ml}$ methanol and marking up to $10 \mathrm{ml}$ volume, from this solution $1 \mathrm{ml}$ aliquot was pipette out and diluted to $10 \mathrm{ml}$ using methanol to get final concentration of $100 \mu \mathrm{g} / \mathrm{ml}$. Working standards of $0,5,10,15,20,25$ and $30 \mu \mathrm{g} / \mathrm{ml}$. were prepared by serial dilutions.

A stock solution of rutin was prepared by dissolving $10 \mathrm{mg}$ of rutin in $2 \mathrm{ml}$ methanol and marking up the volume to $10 \mathrm{ml}$, from this solution $1 \mathrm{ml}$ was pipette out and diluted to $10 \mathrm{ml}$ by using methanol to get final concentration of $100 \mu \mathrm{g} / \mathrm{ml}$. Working standards of $0,5,10,15,20,25$ and $30 \mu \mathrm{g} / \mathrm{ml}$ were prepared by serial dilutions (Suman et al., 2014).

\section{Extraction of Total Phenolic Content}

$100 \mathrm{~g}$ of each of the vegetable samples was finely ground. $10 \mathrm{ml}$ of aqueous acetone (70\%) was added to $400 \mathrm{mg}$ of the powder and suspended in water bath for $20 \mathrm{~min}$ at room temperature. The suspension was transferred to centrifuge for $10 \mathrm{~min}$ at $3000 \mathrm{rpm}$. The supernatant was diluted with methanol to achieve a volume of $10 \mathrm{ml}$ and kept in an ice (supernatant A). Each plant sample was extracted three times.

\section{Quantitative Determination of Total Phenolic} Content

$200 \mu \mathrm{L}$ of supernatant A was transferred to a test tube (4tube/sample) and dried. $600 \mu \mathrm{L}$ of sulfuric acid $(0.2 \mathrm{~N})$ was added to the test tubes. To three tubes, $900 \mu \mathrm{L}$ of Rhodanine solution $(0.667 \%)$ was added and to the fourth tube $900 \mu \mathrm{L}$ of methanol was added. The fourth tube was set as a blank. After 10 $\min 600 \mu \mathrm{L}$ of potassium hydroxide solution $(0.5 \mathrm{~N})$ was added to all of the test tube. 6 min later $13 \mathrm{~mL}$ of distilled water was also added. After $25 \mathrm{~min}$ the absorbance of red -purple solution was measured at $520 \mathrm{~nm}$ against the blank using Varian UV-Vis spectrophotometer (Cary 50 Bio UV-Vis Spectrophotometer, Varian).The concentration of total phenolic content in the test samples was obtained from the calibration plot of standard by interpolation and expressed as $\mathrm{mg}$ gallic acid equivalent (GAE)/g of dried plant material. All the determinations were carried out in triplicate (Mahdi et al.,2011).

\section{Extraction of Total Flavonoid}

$1 \mathrm{~g}$ each of the dried vegetable samples was used for the preparation of the extract. Samples were extracted with $7.5 \mathrm{~mL}(95 \% \mathrm{v} / \mathrm{v})$ ethanol at $40^{\circ} \mathrm{C}$ for $10 \mathrm{~min}$; the extraction process was repeated thrice. The solvent was evaporated at $40^{\circ} \mathrm{C}$. The dried extract was used for further analysis (Suman et al., 2014).

\section{Sample Preparation}

$50 \mathrm{mg}$ of the extract was dissolved in $5 \mathrm{~mL}$ methanol and sonicate for 45 minutes at $40^{\circ} \mathrm{C}$ followed by centrifugation at $1000 \mathrm{rpm}$ for $10 \mathrm{~min}$. The clear supernatant solution was collected and used for analysis.

\section{Determination of total flavonoid}

$0.6 \mathrm{~mL}$ of supernatant solution was separately mixed with $0.6 \mathrm{~mL}$ of $2 \%$ aluminum chloride. After mixing, the solution was incubated for $60 \mathrm{~min}$ at room temperature. The absorbance of the reaction mixtures was measured against blank at $420 \mathrm{~nm}$ wavelength with a Varian UV-Vis spectrophotometer model (Cary 50 Bio UV-Vis Spectrophotometer, Varian). The concentration of total flavonoid content in the test samples was obtained from the calibration plot by interpolation and expressed as $\mathrm{mg}$ rutin equivalent $(\mathrm{RE}) / \mathrm{g}$ of dried plant material. All the determinations were carried out in triplicate (Suman et al., 2014).

\section{Results and Discussion}

Figure 1 showed that, Okra from Bebeji had the highest amount of total phenolic content of $33.33 \pm$ $0.03 \mathrm{mg} / \mathrm{g}$ GAE among the various samples evaluated, followed by Tudun wada sample $32.03 \pm 0.05 \mathrm{mg} / \mathrm{g}$ $\mathrm{GAE}$. Kura sample was found to have the least phenolic content of $22.07 \pm 0.02 \mathrm{mg} / \mathrm{g}$ GAE compared to other samples analyzed. Various values have been previously reported for total phenolic contents of vegetables, which includes, $49.72 \pm 2.24 \mathrm{mg} / \mathrm{g}$ GAE of total phenolic content in Okra ( Rohman et. al.,2010). Ebrahimzadeh et. al., (2009), reported the total phenolic content of $68.81 \pm 3.90 \mathrm{mg}$ gallic acid equivalent/g of extract in Okra. Jin-Yuarn and Chinyun., (2007), reported the levels of total phenolic content in Mulberry and Onions, $1515.9 \pm 5.70 \mathrm{mg}$ gallic acid equivalents (GAE)/100g fresh matter of total phenolic in Mulberry and $310.8 \pm 4.9 \mathrm{mg}$ $\mathrm{GAE} / 100 \mathrm{~g}$ fresh matter of total phenolic content in Onions. Hung et. al.,(2012) also reported the total phenolic content in Carrot, Taro, Tomato, Beet root and Egg plant as $36.60 \pm 0.50,93.50 \pm 0.90,61.20 \pm$ $0.70,229.20 \pm 1.60,454.50 \pm 0.50 \mu \mathrm{g} \mathrm{GAE} / \mathrm{g}$ sample respectively. In Figure 2 Minjibir sample had the highest amount of flavonoid content of $29.979 \pm 0.036 \mathrm{mg} / \mathrm{g}$ RE in okra among the various sampling areas investigated. This is followed by Bebeji sample 25.313 $0.051 \mathrm{RE}$ whereas Chalawa sample has the least flavonoid content of $10.979 \pm 0.095 \mathrm{mg} / \mathrm{g}$ RE. Flavonoid content have been previously reported from vegetables, which include, $31.21 \pm 8.64 \mathrm{mg} / \mathrm{g}$ RE of flavonoid content in okra (Rohman et. al., 2010). 
Ebrahimzadeh et. al., (2009), reported flavonoid content of $49.3 \pm 2.2 \mathrm{mg} / \mathrm{g}$ quercetin equivalent in okra. Jin-Yuarn and Chin-yin., (2007), reported the levels of flavonoid content in mulberry and Onions, $250.10 \pm 6.30 \mathrm{mg}$ quercetin equivalents $(\mathrm{QE}) / 100 \mathrm{~g}$ fresh matter of total flavonoid content in mulberry,
$310.8 \pm 4.9 \mathrm{mg} \mathrm{GAE} / 100 \mathrm{mg}$ quercetin equivalents $(\mathrm{QE}) / 100 \mathrm{~g}$ fresh matter flavonoid content in onions. Hung et. al.,(2012) had earlier reported the total flavonoid contents of carrot, taro, tomato, beet root and egg plant as 11.2, 7.1, 14.7, 15.3, $42.1 \mu \mathrm{g} \mathrm{RE} / \mathrm{g}$ respectively.

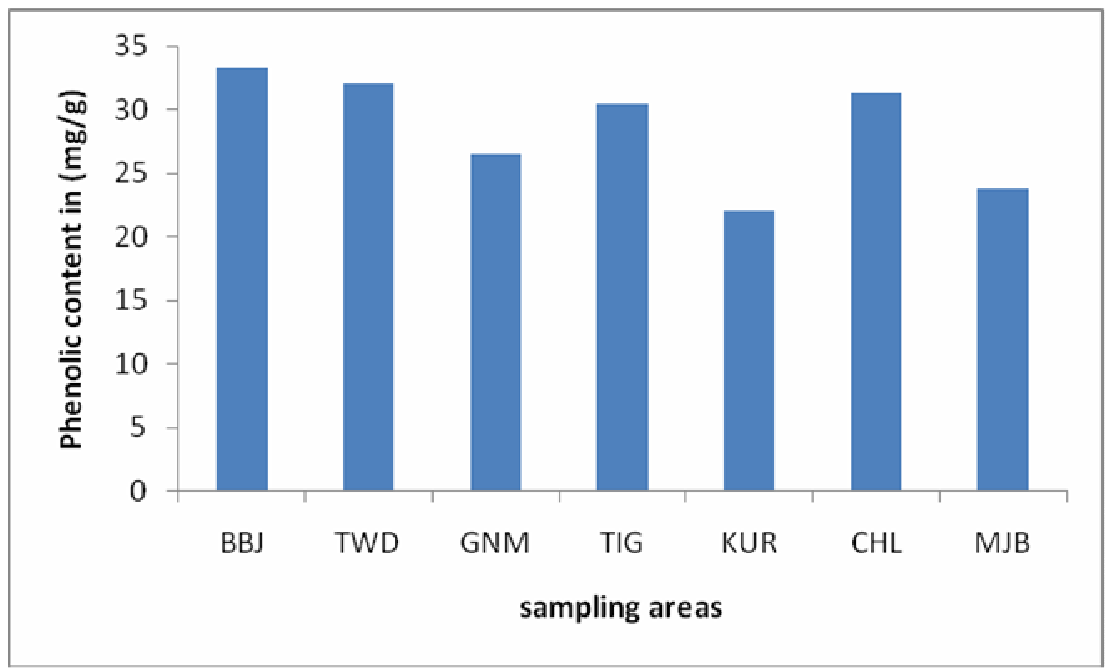

Figure 1: Mean concentration of total phenolic content in okra from the sampling areas Key: BBJ=Bebeji TWD=Tudun Wada GNM=GarunMalam TIG=Tiga KUR=Kura CHL=Chalawa MJB=Minjibir

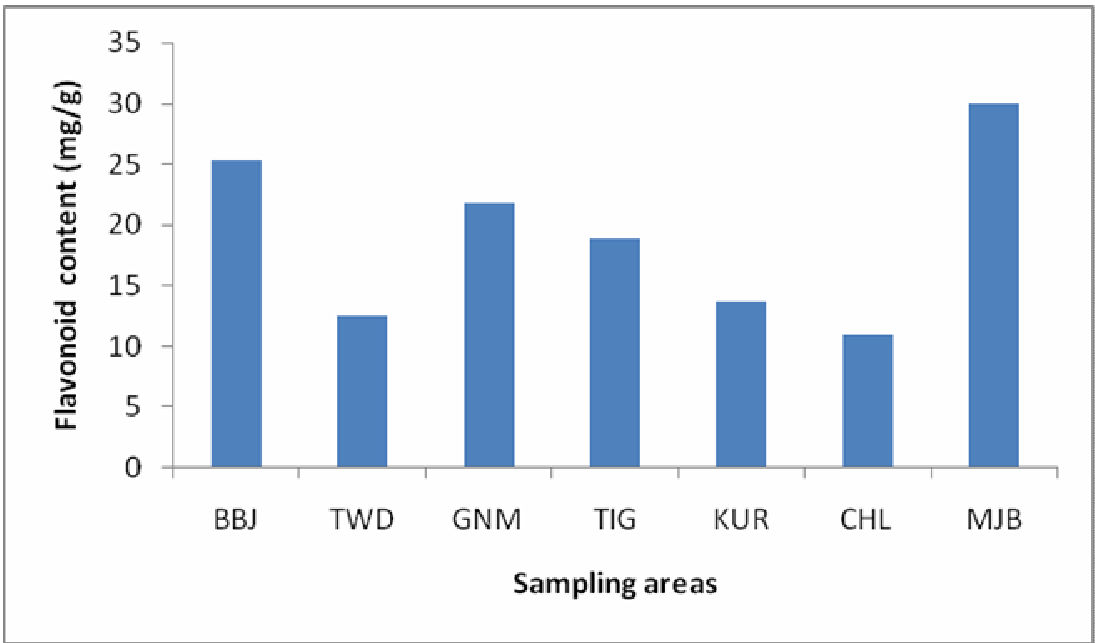

Figure 2: Mean concentration of flavonoid content in Okra from the sampling areas Key: BBJ=Bebeji TWD=Tudun Wada GNM=GarunMalam TIG=Tiga KUR=Kura CHL=Chalawa MJB=Minjibir

\section{Conclusion}

The present study estimated the levels of total phenolic (TPC) and Flavonoid (TFC) contents in Okra vegetables widely available in Kano state, Nigeria.The Okra vegetable analyzed displayed high level of total phenolic (TPC) and Flavonoid contents (TFC). Therefore, this vegetable may be considered as good source of the bioactive compounds and antioxidant.

\section{Recommendations}

Further studies on the effective of antioxidants activity contained in this vegetable, other bioactive compound and the mechanisms by which they protect against disease development are highly recommended.

\section{Contribution}

We were able to quantify the values of total phenolic and flavanoid in okra samples consumed in Kano State, Nigeria. The values will serve as a guide to farmers and consumers of the okra in deciding the types of crops that can be planted and possibly consumed. 


\section{REFERENCES}

Adelakun OE, Oyelade OJ, Ade-Omowaye BI, Adeyemi IA, Van de Venter M. (2009). Chemical composition and the antioxidative properties of Nigerian Okra seed (Abelmoschus esculentus Moench) flour. J Food Chem. Toxicol.;47:1123-6.

Arapitsas P (2008). Identification and Quantification of Polyphenolic Compounds from Okraseeds and Skins. J. Food Chem.;110:1041-5.

Ebrahimzadeh M. A., Nabavi S. F. and Nabavi S. M. (2009) .Antihemolytic and antioxidantactivity of hibiscus Esculentus Leaves. Pharmacologyonline 2: 1097-1105

Haibing L.,Weng D., Xiangjun S., Hualiang L. and Ke Y.(2012).Analysis and composition of active component and antioxidant activities of Okra extract. Magazine; 8(30):156-161

Hung, P. V. and Duy, T. L (2012).Effects of drying methods on bioactive compounds of vegetables and correlation between bioactive compounds and their antioxidants. International Food Research Journal 19(1): 327-332

Jin-Yuarn L. and Ching-Yin T. (2007).Determination of total phenolic and flavonoid contents in selected fruits and vegetables, as well as their stimulatory effects on mouse splenocyte proliferation, Food Chemistry, volume 101, Pages 140-147.

Kang BK, Gagan J, Sharma RK, Battu RS, Singh B (2010). Persistence of propargite on Okra under subtropical conditions at Ludhiana, Punjab, India. Bull Environ ContamToxicol;85:414-8.
Mahdi V., MahnazK. ,Yaghoub A. and Homa H. (2011). Quantification of Gallic Acid in Fruits of Three Medicinal Plants, Iranian Journals of Pharmaceutical Research; vol. 10(2):233236.

Rohman, A., Riyanto, S., Yuniarti, N., Saputra, W. R., Utami, R. and Mulatsih, W.(2010). Antioxidant activity, total phenolic, and total flavaonoid of extracts and fractions of red fruit (Pandanusconoideus Lam). International Food Research Journal 17: 97-106.

Scalbert, A. and Williamson, G (2000). Dieterintake and Bioavailability of Polyphenols. J. Nutr.;130 (8S Suppl):2073S-85S.

Singh U., A. Suman, M,Sharma, J. Singh, A. Singh and S. Maurya (2007). HPCL Analysis of the phenolic profiles in different parts of chilli (Capsicumnnun) and Okra (Abelmuschus esculentus).The internet journals of alternative of alternative medicine;5:2.

Suman, C., Shabana K., Bharathi, A., Hemant, L., Min, H. Y., Mahmoud A. E., and Ikhlas A. K. (2014). Assessment of Total Phenolic and Flavonoid Content, Antioxidant Properties, and Yield of Aeroponically and Conventionally Grown Leafy Vegetables and Fruit Crops: A Comparative Study. EvidenceBased Complementary and Alternative Medicine; 20:14-9 